\title{
網狀內皮組織系統機能卜異稙赤血球 貪食作用卜ノ關係（第II回報告）
}

\section{免疫抗體產生卜異種赤血球頜食作用}

トノ關係

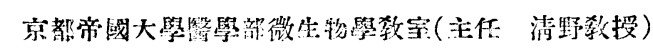

高崎文雄

目光

\begin{abstract}
緒言
第1章 军驗方法

第2意 谈藮䒺芠生卜異種赤血球含食作目卜，關俰

第 1 節 捗窒扶斯菌液 1 回注射的異種赤血球貪食作用

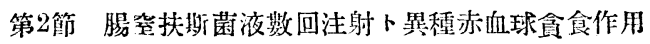

第3章 溶血素座生卜異種赤血球食食作用卜 /關係

第1節 山羊血球液 1 回注射卜姐種躵血球領食作用

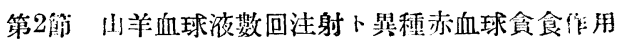

第4亭 沈降素应生卜舆種赤血球含食作用卜，關保

第 1 節 健常馬血泞 1 [以注射卜異種赫助球亘食作用

. 第2節 健常馬血潾數回注射卜筫種赤血球食食作用

第5章 總括及考按
\end{abstract}

結 論

交应

\section{緒言}

免度抗體産生时地八研究”, 從來多數〉學者ニョリテナサル、處ニシテ, 》

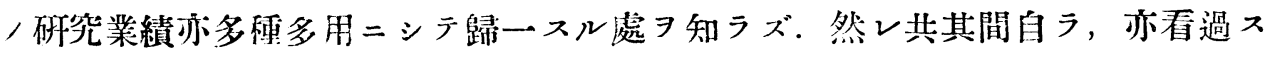

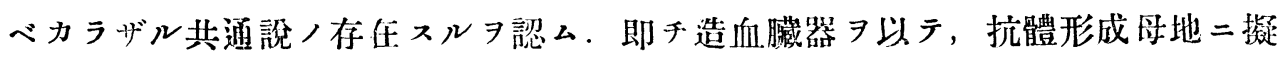
スル者多キ點之レナリ。今凝集素, 溶血素及沈降素產生母地二關スル, 從來, 主ナル學者ノ業䋶ヨ見ル二,

1, 凝集素：凝集素八白血球 7 以テ，其形成母地二擬七片學者（Drlyer u.

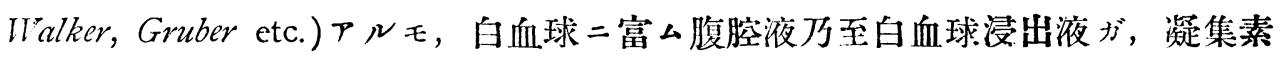

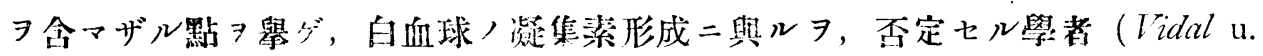


Sicart, Aschard, Bansaude etc.) 多シ.

Pfeiffer u. Marx $x_{(11)}$ ここら菌二對スル凝集素メ，脾臟內二於テ血清中ョリ多

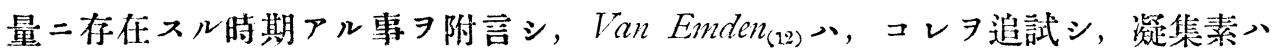
造血臟器二於テ，形成サル、モノニシテ，ソノ際脾臟寺トシテ之レニ當》，骨 髓ハ最モ逰ク且ツ長ク凝集素形成二關與スルタ確メ，更二 Jatta $(13)$ ハ, コレヨ 反覆追試シ, 脾臟ノ凝集素發生母地タル 承認セリ，又 Deutsch( $(14)$ 、膓堂扶斯 菌ヨ用市テ, 凝集素形成卜造血臟器卜ノ間二一定ノ關係习認メタリ.

コレニ反シテ Rath(1i) 、脾臟摘出動物, 凝集素 7 檢シ, 對照二比シ火差ナキ

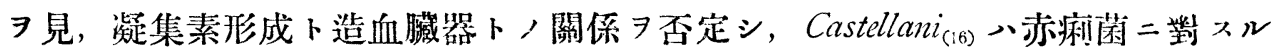

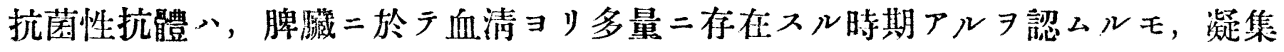

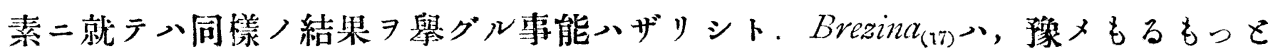

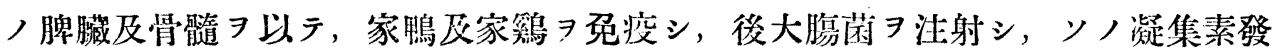
生ヨ見ル二, 著シク障碍サル、カ, 又心全ク發生セラレザルョ見, 從ツテ造血 臟器卜凝集素ノ發生トノ間ニメ, 明ラカニ關係アルラ認メタリ。文网田(9) 墨汁 $\exists$ 以造血藏器, 機能 $\ni$ 障碍 迟セルョ認メ, 凝集素產生母地トシテ, 組織球細胞ガ重大ナル意味ヨ有スル事

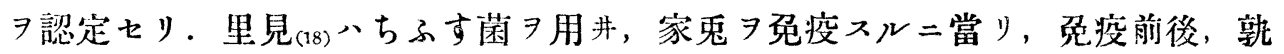
レノ塲合二脾臟 $コ$ 剔出スルモ, 血清中ノ凝集素產生量ノ减退 生母地 , 造血藏器, コトニ脾二求メントセリ。

2. 溶血性抗體：Metschinikoff 心溶血素發生母地トシテ, 所謂大喰細胞 Makrophagen 二富么臟器 $\ni$ 擬シ, 脾臟乃至淋巴腺ハ, 己二健康ナル狀態二於テ, 其浸出液中二, 溶血素ノ含蓄セラル、ノミナラズ, 㣻疫動物二於テ八, 殊二多

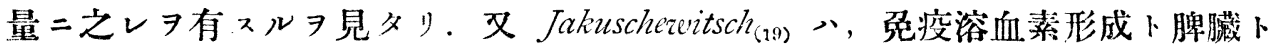
, 關係习, 家兔, るるもっ民, 山羊等二就テ, 研究セル二, 溶血素心, 決シテ 獨り脾藏二於テノミ形成セラル、者ニアラザルぶキヨ揚言シ, 脾臟摘出動物二 於テ, 溶血素ノ多量ノ產出 9 見タルハ, 恐ラク骨髓ノ代償的機能昂進, 及脾藏 摘出二續發七ル自血球增多症ニヨルベシトナシ, 白血球 二擬セり。柇田(20)

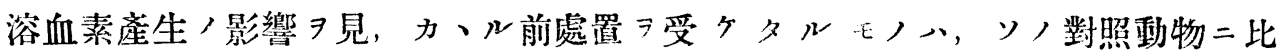




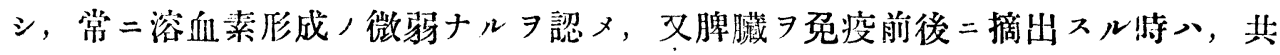
二溶血素產生入, 對照動物二比シ减弱七ルヨ認メ, 網狀內皮細胞ハ, 少ナクト モ溶血素形成民地トシテ, 重要ナル意義 第 2 回報告, らって, 脾抗體產生二及ボス影響二於テ, 家兔二比シ, 更二大ナ ル脾ヨ有シ, 之レガ剔出 7 行フ時ハ, 肝二恰カモ脾細胞二酷似スル, 網狀織細 胞 7 新生スル事顯著ナル動物, らって 苑疫前後二亘リテ, 脾 7 剔出セバ, 大體二於テ, 抗體價, 低下 テ, 脾八凝集素, 並二溶血素產生二關シ, 重要ナル機能ヨ營ムモノナリト言一 リ. 高畑及岩井(1) 成熟家兔 明ナル變化 認メズ, 又血清醏素作用ノ差異著シカラザルニ反シ, 特殊性溶血

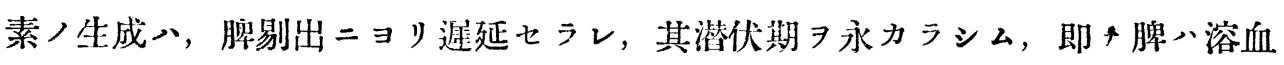
素生成ニハ重要ナル機能ヨ營ム一臟器ナリト斷ゼリ.

3, 沈降素：Kraus u. Levaditi 八家鬼八腹腔內二, 馬血清 7 注射シ, 一定時 間 $\exists$ 經テ, 各茈器浸出液內二於ヶル, 沈降素, 含有量 $\exists$, 測定セルニ, 末ダ何

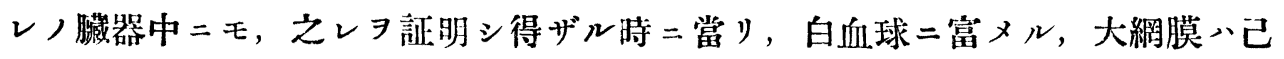
二, 沈降素ヨ含ム 7 見ル, 從シテ同氏等ハ, 白血球ハ沈降素形成ニアッ゙カル可

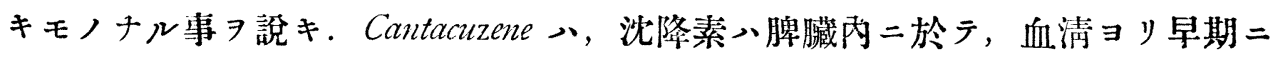
發現スル 言証シ, 免疫性沈降素ノ形成母地 7 , 白血球, 殊二單核性白血球于

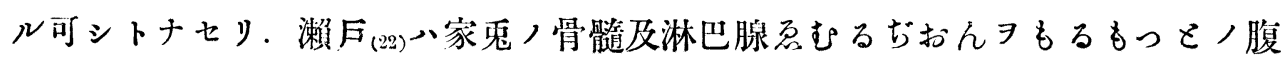
腔二, 注射シ斯クシテ得タル，るるっとト血清ヨ用市，即チちををきしんノ 破壞若クハ, 刺戟作用 $ᄏ$ 利用シテ, 無牌立二健常家鬼體內二於ヶル沈降素, 並

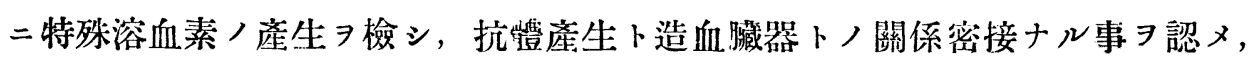
脾, 骨髓, 淋巴腺ヨ以テ其主要產生ナラント結論七リ。

以上, 㤝疫抗體, 就中凝集素, 溶血素及沈降素, 產生地二關スル, 諸實驗, 學說 $\ni$ 通臨スルニ, 所謂造血臟器 ク之二反シ, 抗體産生二そボス造血臟器ノ影響习認メザルカ, 若クバ尠クトモ 之ヨ重シトナサ、ルモノ, 又抗體局所產生 (Wassermann u. Citron $(2 ;)$ ) 諒クモ ノ，血液内抗體産生 $习$ 認ムルモノ，又生體染色二一程度艺陽性ナル細胞種，特

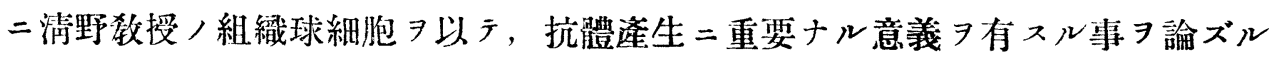




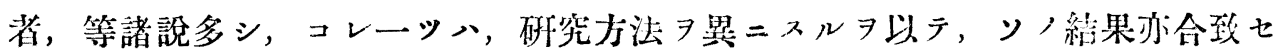

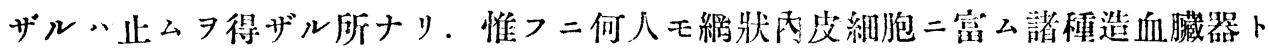
免疫抗腽產生トノ間二重要ナル關係アルョ否ム事能ハザルベシ.

余八, コレ等網狀内皮細胞, , 諸種免疫物質 $コ$ 以テ影響シ, ソノ機能ノ變化 ヨ知ラントセリ, 以下ンノ硬概ヨ報告セントス。

\section{第 1 章 赛 驗 方 法}

實驗動物ハ凡テ家鬼 用㐋タリ。

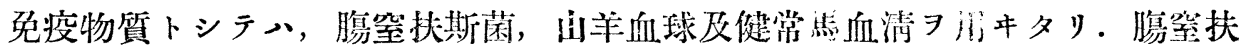

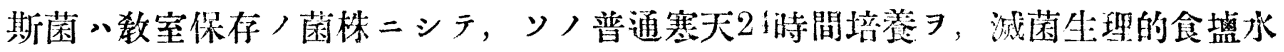
$1.0 \mathrm{cc}=1.0 \mathrm{mg} /$ 比二浮游セシモノ

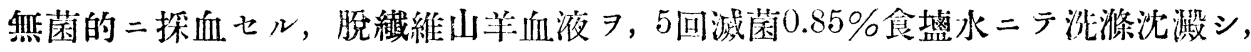
ソ八血球, 一定量 7 注射用二供シ, ソノ血球ノ 40 㶵狶䆁液 7 溶血反應二, 又ソ , 200 倍稀釋液 , 血球凝集反應二用市タリ. 又沈降素產生試驗二八, 健常馬 血清 以ラ免疫原及反應元トナ七り。

機能檢查用トシテノ鴙血球ハ，第 1 回報告二詳述セり.

\section{第 2 章 凝集素産生卜異種赤血球責食作用}

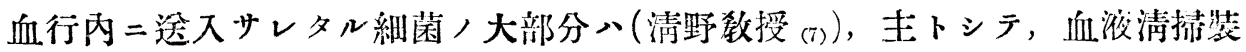
置ノ組織球細胞ニョリ食食七ラル, 又淋巴路ョリ迳入七ラレタル細菌ガ淋巴清 掃裝置二多ク，沈着スル事勿論ナリ。而シテ是等清拈裝置タル組織球性細胞

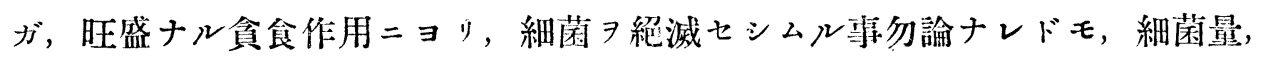

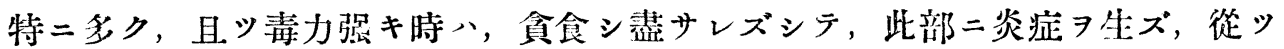
テ，是等清掃組織八，細菌侵襲時二八，犯サレヤスキ部位タルヨ孕レズ. 又

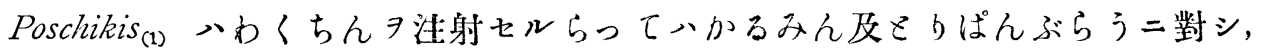

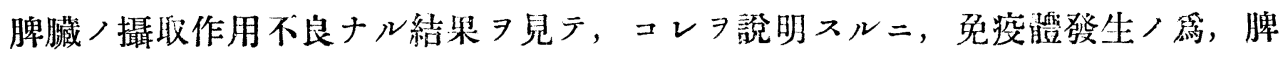
臟內綳狀內皮細胞ノ攝取機能ガ著シク减退セルニ因ルモノナリト，ナセり。

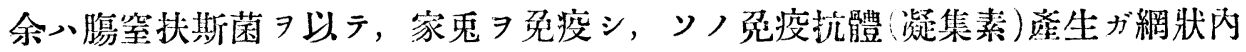
皮細胞ノ機能二如何ナル變化ヨ與フベキカヨ，實驗セリ. 


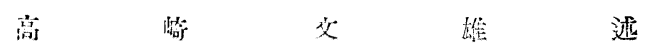

(349)

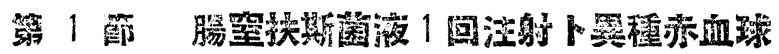 䨘食作用}

\begin{tabular}{|c|c|c|c|c|c|c|c|c|c|c|c|c|c|c|c|c|c|}
\hline \multirow{2}{*}{ 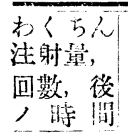 } & \multirow{2}{*}{$\begin{array}{l}\text { 家息 } \\
\text { 番號 }\end{array}$} & \multirow{2}{*}{ 性 } & \multirow{2}{*}{$\begin{array}{l}\text { 呰重 } \\
(\mathrm{g})\end{array}$} & \multirow{2}{*}{ 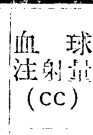 } & \multicolumn{11}{|c|}{ 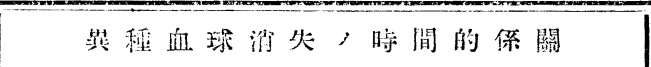 } & \multicolumn{2}{|c|}{ 凝䈍䨘 } \\
\hline & & & & & 15 si & 30 分 & 45 分 & 1時 & 4 & 2 诗 & 14 & 3时 & 4 洔 & 5時 & 6 時 & 前 & 後 \\
\hline \multirow{2}{*}{ 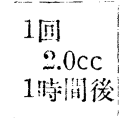 } & 第1號 & 俳 & & & + & $t$ & & + & + & + & + & $1+$ & + & +1 & $1+1$ & & 80 倍 \\
\hline & 第2號 & 雄 & & & & $1+$ & + & +1 & + & + & + & + & $1+$ & $1+1$ & $1-1$ & 60倍 & \\
\hline \multirow{2}{*}{$\begin{array}{c}1 \text { 回 } \\
0.2 \mathrm{cc} \\
1 \text { 跱洞後 }\end{array}$} & 第3 號 & $\mid$ 此位. & & & + & + & +1 & $1+1$ & $1+$ & + & + & + & 死 & & & 60 倍 & 60倍 \\
\hline & 第4 號 & 维 & & & + & + & + & +1 & + & + & + & +1 & + & -1 & $1-1$ & 40 倍 & 保 \\
\hline \multirow{2}{*}{$\begin{array}{c}1 \text { 回 } \\
2.0 \mathrm{ccc} \\
24 \text { 時間後 }\end{array}$} & 第5號 & 雄: & & & $T$ & + & + & +1 & 1 & + & +1 & $1+1$ & $1-$ & -1 & $1-1$ & 40 倍 & 80 倍 \\
\hline & 第6 躆 & 雄: & 2000 & & & + & & +1 & + & + & + & $-\cdots$ & -1 & $1-1$ & $1-1$ & 60倍 & 80 倍 \\
\hline \multirow{2}{*}{\begin{tabular}{c|}
1 回 \\
$2.0 \mathrm{cc}$ \\
7 後
\end{tabular}} & & 碓: & & & + & + & + & + & + & -1 & -1 & -1 & - & -1 & $1-1$ & \multicolumn{2}{|c|}{20 倍 1280 倍 } \\
\hline & 第8號 & 雉 & & & +1 & $1+$ & +1 & $1+1$ & +1 & -1 & -1 & $1-1$ & - & -1 & $1-1$ & 40 倍 & \\
\hline
\end{tabular}

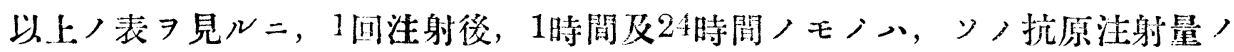

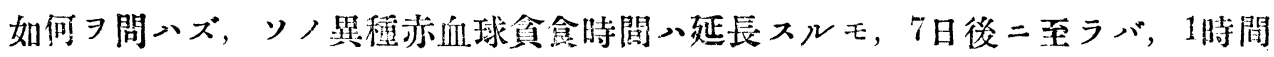

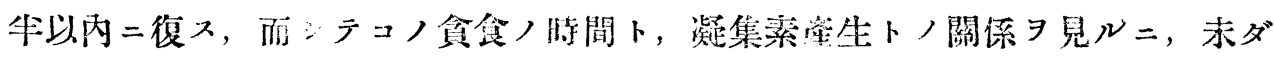

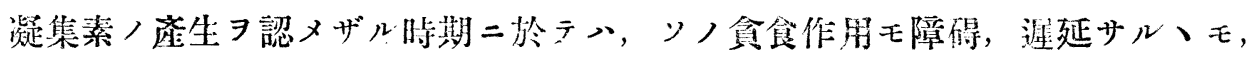

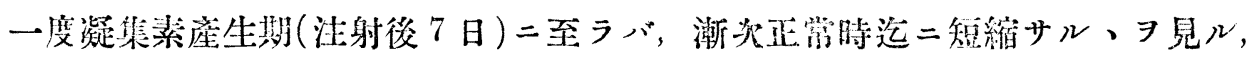

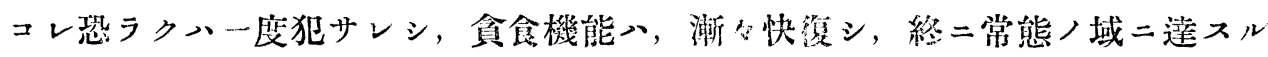

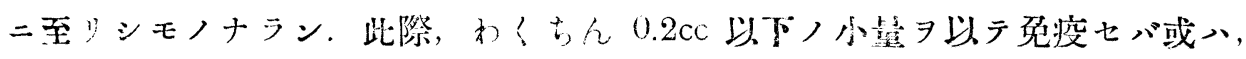

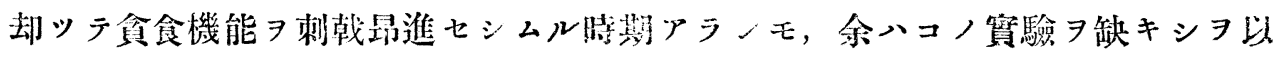
テ，唯推定二此メン.

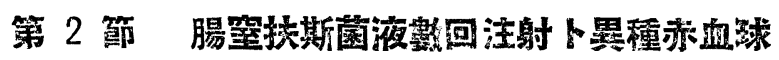 寊食作用}

第 2 表

\begin{tabular}{|c|c|c|c|c|c|c|c|c|c|c|c|c|c|c|c|c|c|}
\hline \multirow{2}{*}{ 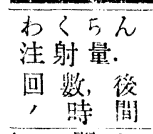 } & \multirow{2}{*}{$\begin{array}{c}\text { 家忽 } \\
\text { 踾號 }\end{array}$} & \multirow{2}{*}{ 性 } & \multirow{2}{*}{\multicolumn{3}{|c|}{$\begin{array}{l}\text { 糟西血 球 } \\
(\mathrm{g})(\mathrm{cc})\end{array}$}} & \multicolumn{10}{|c|}{ 珙種血球淮先，時間的阔你 } & \multicolumn{2}{|c|}{ 凝 態價 } \\
\hline & & & & & & 30 分 & 45 分 & 1時 & 本 & 2時 & 4 & 3 暗 & 4 踇 & 洔 & 6 的 & 萌 & 後 \\
\hline $\begin{array}{l}44 \text { ，問隔= } \\
\tau 44 \text { 回 }\end{array}$ & 策 9 號 & 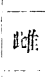 & 2300 & 11.5 & + & + & - & - & - & - & - & - & -1 & - & - & 10 倍 & 5000 倍 \\
\hline $\begin{array}{c}0.5-2.0 \mathrm{cc} \text { 这 } \\
5 \mathrm{H} \text { 後 }\end{array}$ & & & & & + & + & + & & & -- & -- & & & - & - & 倍 & \\
\hline
\end{tabular}




\begin{tabular}{|c|c|c|c|c|c|c|c|c|c|c|c|c|c|c|c|c|c|}
\hline \multirow{2}{*}{$\begin{array}{l}\text { わくちん } \\
\text { 注射量, } \\
\text { 回 鹳, 後 } \\
\text { 時間 }\end{array}$} & \multirow{2}{*}{$\begin{array}{l}\text { 家鬼 } \\
\text { 番號 }\end{array}$} & \multirow{2}{*}{ 性 } & \multirow{2}{*}{$\mid \begin{array}{l}\text { 體重 } \\
(\mathrm{g})\end{array}$} & \multirow{2}{*}{$\begin{array}{l}\text { 血 球 } \\
\text { 注射 } \\
\text { (cc) }\end{array}$} & \multicolumn{11}{|c|}{ 異種血球消失人時間的關俰 } & \multicolumn{2}{|c|}{ 凝 集 價 } \\
\hline & & & & & 15 分 & 30分 & 45 分 & 1 時 & 半 & 2時 & 牛 & 3時 & 4 時 & 知時 & 6時 & 前 & 後 \\
\hline $\begin{array}{l}\text { 4日，間隔= } \\
\text { テ6回 }\end{array}$ & 第11號 & 雄 & 2300 & 11.5 & + & + & + & + & + & - & - & - & - & - & - & 10倍 & 3000 \\
\hline $\begin{array}{c}0.5-2.0 \mathrm{cc} \text { 沦 } \\
5 \quad \mathrm{~B} \text { 後 }\end{array}$ & 第12號 & 雄 & 2100 & 10.5 & + & + & + & + & + & - & - & - & - & - & - & 20倍 & 3000倍 \\
\hline $\begin{array}{l}4 \text { 4月，雷隔 }= \\
\text { テ8回 }\end{array}$ & 第13號 & 䧸 & 2100 & 10.5 & + & + & + & + & - & - & - & - & - & - & - & 20 倍 & 2000倍 \\
\hline $\begin{array}{l}0.5-2.0 \mathrm{cc} \text { 沦 } \\
5 \text { 日 後 }\end{array}$ & 掻14號 & 蜼 & 2000 & 10.0 & + & + & + & + & $t$ & - & - & - & - & - & - & 20 倍 & 100 \\
\hline $\begin{array}{l}\text { 每日 } 1.0 \mathrm{cc} \\
5 \text { 回 }\end{array}$ & 第15號 & 雄 & 1300 & 6.5 & + & + & + & - & - & - & - & - & - & - & - & |30倍| & 4000倍 \\
\hline 24時間後 & 第16號 & 雄 & 1500 & 7.5 & + & + & + & - & - & - & - & - & - & - & - & 60 㒀 & 5000倍 \\
\hline $\begin{array}{l}\text { 每日 } 1.0 \mathrm{cc} \\
14 \text { 回 }\end{array}$ & 第 17 號 & 维 & 1700 & 8.5 & + & + & - & - & - & - & - & - & - & - & - & 20 倍 & 10000倍 \\
\hline & & & & 0.0 & $T$ & - & - & - & & - & - & - & - & - & - & 01 & 0倍 \\
\hline
\end{tabular}

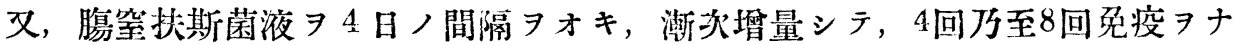
シ, ソノ免疫完了後 5 日ニシテ, ソノ舍食機能 $\ni$ 檢七ル二, 何レモ正常家鬼, ソレ或ハソレ以內二短縮サル，コトニ每日 $1 \mathrm{cc}$ 宛漸續注射, 5 回或ハ14回二及心

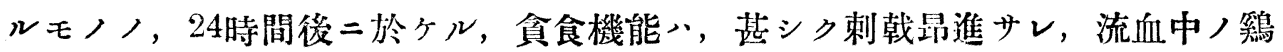
血球 45 分乃至, 30 分以內二消失スル 認么。

\section{第 3 章 溶血素産生畋種赤血球實食作用 ト關係}

溶血素產生母地トシテ, 重大ナル關係 ヨ有ス, トナサル、造血臟器ノ機能 八, 山羊血球, 注射ニョリテ, ソノ機能ノ變化 來スヤ, 推定二難カラザルベ シ, 余八山羊血球 $\ni$ 以テ, 家鬼 7 免疫シ, ソノ溶血素產生卜，更二注入七シ鷄 赤血球食食作用卜ノ間二, 亦一定ノ關係 見出サントセリ.

此際乔疫原注射量入，1回注射ノモノ八，20.0\% 10.0cc或、5.0\% モ, $2.0 \mathrm{cc}$ ヨ用年，蓮續數回注射ノモノニ八，一定ノ間隔ヨオキ注射セシモノト。每日連

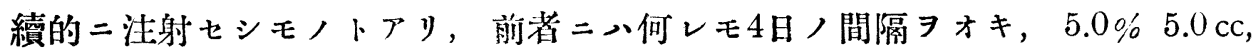
$10.0 \% 5.0 \mathrm{cc}, 20.0 \% 5.0 \mathrm{cc} ，$ 血球原液 $2.0 \mathrm{cc}$ 注射シ，後者二八，每回， $20.0 \%$

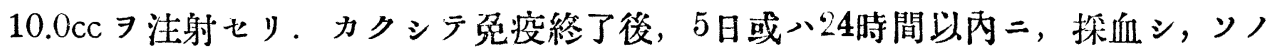
溶血價 7 測定スルト同時二, 機能檢査 7 試ミタリ.

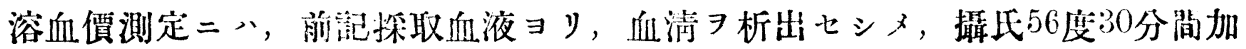


温シ，非動性トナシ，生理的食坫水ア以テ法ノ如ク稀釋シ, ソノ1.0 cc ヅ、ヨ試 驗管二採り之二 10 倍稀釋

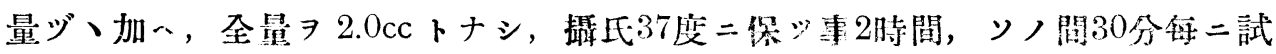

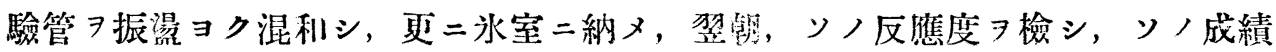
$\exists$, 完全溶血, 强度溶血, 弱度溶血, 微溶血, 痕跡, 㓌性, 二分テリ。 又血球 凝集素反應ニハ200倍稀釋山羊白血球液 用立タリ。

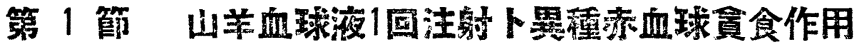

第。 3 表

\begin{tabular}{|c|c|c|c|c|c|c|c|c|c|c|c|c|c|c|c|c|}
\hline \multirow{2}{*}{ 香㩆 } & \multirow{2}{*}{$\begin{array}{l}\text { 目羊血球注射 } \\
\text { 回數, 量, } \\
\text { 後 }\end{array}$} & \multirow{2}{*}{$\begin{array}{ll}\text { 家 } & \text { 费 } \\
\text { 番 } & \text { 䖓 }\end{array}$} & \multirow{2}{*}{ 性 } & \multirow{2}{*}{$\begin{array}{l}\text { 體重 } \\
(\mathrm{g})\end{array}$} & \multirow{2}{*}{ 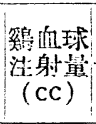 } & \multicolumn{11}{|c|}{ 異種血球消失，時間的關你 } \\
\hline & & & & & & & 30 分 & 45 分 & 1時 & $4:$ & 2 時 & 4: & 3時 & 4 时 & 5 時 & 6 時 \\
\hline \multirow{2}{*}{1} & \multirow{2}{*}{ 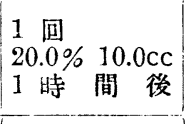 } & 第19號 & 雄 & 2000 & & + & + & + & + & + & + & + & - & $|-|$ & - & - \\
\hline & & 第20號 & & & & + & + & + & + & + & + & - & -1 & -1 & $1-$ & - \\
\hline & \multirow{2}{*}[\begin{array}{rr}{1}&{\text{回}}\\
{5.0\%}&{2.0\mathrm{cc}}\\
{11\text{時}}&{\text{䦗後}}\end{array}]{} & & & & & & + & + & + & + & +1 & $1+$ & + & $1-1$ & $1-1$ & $1-$ \\
\hline & & & & & & & + & + & + & + & +1 & + & + & +1 & -1 & $1-$ \\
\hline & \multirow{2}{*}{\begin{tabular}{|ll}
1 & 回 \\
$20.0 \%$ & $10.0 \mathrm{cc}$ \\
24 時 酒 後
\end{tabular}} & 第 23 號 & 雄 & 2000 & 10.0 & + & + & + & + & + & +1 & $1+$ & - & -1 & - & - \\
\hline & & 第24號 & $a_{1: 2}$ & & & + & + & + & + & + & +1 & $1+$ & - & -1 & -1 & $1-$ \\
\hline & \multirow{2}{*}{$\left|\begin{array}{ccc}1 & \text { 回 } & \\
20.0 \% & 10.0 \mathrm{cc} \\
5 & \text { 日 } & \text { 後 }\end{array}\right|$} & & 雄. & & & + & + & + & + & + & + & $1+$ & $1-$ & -1 & $1-$ & $1-$ \\
\hline & & & 雄 & & & + & + & + & + & + & +1 & $1-$ & - & $1-1$ & $1-$ & - \\
\hline
\end{tabular}

第 4 表 1 回免疫トソノ溶血價

\begin{tabular}{|c|c|c|c|c|c|c|c|c|c|c|c|c|c|c|c|c|c|c|c|c|}
\hline \multirow[b]{2}{*}{ 番號 } & \multirow{2}{*}{$\begin{array}{ll}\text { 家 } \\
\text { 番 } \\
\text { 號 }\end{array}$} & \multicolumn{6}{|c|}{ 健常溶血霓 健 常 } & \multicolumn{4}{|c|}{ 免 } & \multicolumn{2}{|l|}{ 造 } & \multicolumn{2}{|l|}{ 溶 } & 血. & \multicolumn{2}{|l|}{ 價 } & & \multirow{2}{*}{ 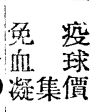 } \\
\hline & & 原 & 2 & 4 & 8 & 16 & 疑集俅 & 原 & 2 & 4 & 8 & 16 & 20 & 50 & 100 & 200 & $500 \mid$ & $1000^{\prime}$ & & \\
\hline \multirow{2}{*}{1} & 第19號 & 弱 & 弱 & 微 & 微 & 痕 & 10 & 微 & 微 & 微 & 微 & 痕 & & & & & & & & 10 \\
\hline & 第20號 & 弱 & 微 & 微 & 痓 & - & 10 & 微 & 微 & 微 & 痕 & - & & & & & & & & 10 \\
\hline \multirow{2}{*}{2} & 第21號 & 弱 & 嫋 & 微 & 痕 & - & 10 & 弱 & 微 & 微 & 微 & - & & & & & & & & 10 \\
\hline & 第22號 & 弱 & 微 & - & - & - & 20 & 微 & 微 & - & - & - & & & & & & & & 20 \\
\hline \multirow{2}{*}{3} & 籍 23 號 & 冴 & 微 & 微 & - & - & 20 & 弱 & 弱 & 微 & 微 & 微 & 微 & & & & & & & 20 \\
\hline & 第24號 & 弱 & 微 & - & - & $\ldots$ & 10 & 弱 & 鵢 & 微 & 微 & 微 & - & & & & & & & 20 \\
\hline & 第25號 & 弱 & 弱 & 微 & 垦 & - & 10 & & & & & & & 完 & 完 & 殆完 & 强 & 弱 & - & 200 \\
\hline & 第 26 號 & 弱 & - & - & - & - & 20 & & & & & & & 完 & 完 & 究 & 强 & 弱 & - & 400 \\
\hline
\end{tabular}


以上ノ2表 テモ，又注射後1時間万至5日二至ルモ，何レモ暴種赤血球舍食時間，延長(2時

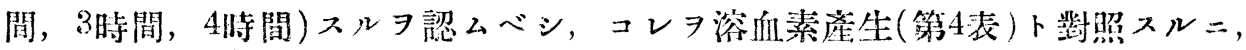
一般二溶血素ノ產生ナキカ，又八輕度二出現スル時期ト一致ス。換言セバ们力 、ル抗體產生不龙分ナル咕期二炵テハ，ソノ会食作用モ亦侵少ル、モノノ如 シ

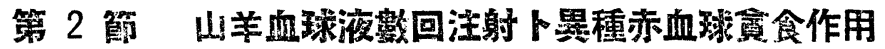

第 5 湴

\begin{tabular}{|c|c|c|c|c|c|c|c|c|c|c|c|c|c|c|c|c|}
\hline \multirow{2}{*}{ 番號 } & \multirow{2}{*}{ 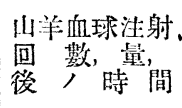 } & \multirow{2}{*}{$\begin{array}{l}\text { 家 鬼 } \\
\text { 香 號 }\end{array}$} & \multirow{2}{*}{ 抄: } & 體重 & 筑血球 & \multicolumn{11}{|c|}{ 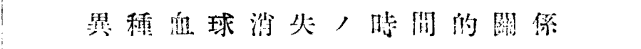 } \\
\hline & & & & $(\mathrm{g})$ & ( CC) & 15 㲾 & 30 分 & 45 分 & 1時 & 乎 & 2時 & 愔 & 3時 & 4時 & 5時! & 6 時 \\
\hline \multirow{2}{*}{5} & \multirow{2}{*}{$\begin{array}{l}4 \text { 回(間隔 } 4 \text { 日 }) \\
5-20 \% 5 \mathrm{cc} \\
5 \text { 日 後 }\end{array}$} & 第27號 & 此隹 & 2100 & 10.5 & + & - & - & - & 一 & - & - & - & - & - & - \\
\hline & & 第28號 & 维: & 2000 & 10.0 & + & + & - & - & - & - & - & - & - & - & - \\
\hline \multirow{2}{*}{6} & 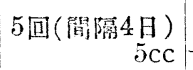 & 第 29 號 & 婎 & 2200 & 11.0 & + & - & - & - & - & - & - & - & - & - & - \\
\hline & 5 日 後 & 第30號 & 堆 & 2100 & 10.5 & + & + & + & - & - & - & - & - & & - & - \\
\hline \multirow{2}{*}{7} & \multirow{2}{*}{$\begin{array}{r}6 \text { 河(閐隔4日) } \\
5 \mathrm{CC} \\
5 \text { 月 }\end{array}$} & 第81號 & 雌 & 2100 & 10.5 & + & + & + & 一 & $\cdots$ & - & -.. & - & & - & - \\
\hline & & 第32號 & 雄 & 2000 & 10.0 & + & + & - & - & - & -- & - & - & - & - & - \\
\hline \multirow{2}{*}{8} & \multirow{2}{*}{ 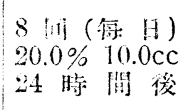 } & 第33號 & 哠 & 1800 & 9.0 & + & - & $\cdots$ & - & 一 & - & $-\cdots$ & - & - & - & - \\
\hline & & 篫34號 & his: & 2000 & 10.0 & + & - & - & - & - & - & - & $\cdots$ & - & - & - \\
\hline \multirow{2}{*}{9} & \multirow{2}{*}{$\begin{array}{l}16 \text { 可 (箈 H) } \\
20.0 \% \% \text { 10.0 } \\
24 \text { 時 閒 }\end{array}$} & 筇30號 & 碓: & 1900 & 9.5 & + & - & - & - & - & $\cdots$ & $\cdots$ & $\cdots$ & - & - & $\cdots$ \\
\hline & & 符36號 & 始: & 2000 & 10.0 & + & + & - & - & - & - & - & - & - & - & - \\
\hline
\end{tabular}

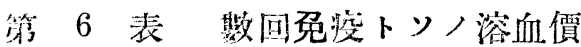

\begin{tabular}{|c|c|c|c|c|c|c|c|c|c|c|c|c|c|c|c|c|c|c|}
\hline \multirow{2}{*}{ 潘躆 } & \multirow{2}{*}{$\begin{array}{l}\text { 要 } \\
\text { 沓 號 }\end{array}$} & \multicolumn{2}{|c|}{ 街: 裳 } & \multicolumn{3}{|c|}{ 溶 血 價 } & \multirow{2}{*}{ 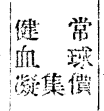 } & \multicolumn{3}{|c|}{ 㣻 } & 萿 & \multicolumn{2}{|c|}{ 溶 } & \multicolumn{2}{|c|}{ 血 } & \multicolumn{2}{|l|}{ 保 } & \multirow{2}{*}{ 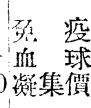 } \\
\hline & & 湟 & 2 & 4 & 8 & 16 & & 1000 & 2000 & & 4000 & 50 & 6000 & 7000 & 8000 & 0000 & 0000 & \\
\hline & 第 27 號 & 弱 & 微 & \% & 微 & - & 20 & 芫 & 完 & 强 & 強 & 弱 & 微 & 微 & 彻化 & - & $\cdots$ & 1000 \\
\hline & 筙28 源 & 弱 & 微 & 微 & - & - & 20 & 芫 & 強 & 强 & 滒 & 微 & 微 & - & - & - & .. & .800 \\
\hline & 管 29 號 & 冴 & 微。 & 微 & 得 & $\ldots$ & 20 & 完 & 然 & 芫 & 强 & 强 & 弱 & 微 & 微 & 微 & $\cdots$ & 800 \\
\hline & 管30號 & 微 & $\cdots$ & - & $\cdots$ & $\cdots$ & 20 & 完 & 完 & 强 & 強 & 暍 & 糅 & 微 & 微 & 微 & - & 1000 \\
\hline \multirow[t]{2}{*}{ - } & 管31號 & 弱 & 微 & 㕍 & 僢 & - & 20 & 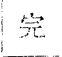 & 完 & 完 & 殆完 & 强 & 强 & 弱 & 雅 & 微 & $\cdots$ & 1600 \\
\hline & 筧 32 㾤 & 武弱 & 诰 & 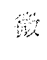 & - & $\ldots$ & 10 & 㫕 & 突 & 完 & 强 & 强 & 弱 & 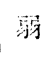 & 得列 & 缆 & $\ldots$ & 1000 \\
\hline
\end{tabular}




\begin{tabular}{|c|c|c|c|c|c|c|c|c|c|c|c|c|c|c|c|c|c|c|}
\hline \multirow{2}{*}{ 番㗈 } & 家 鬼 & & 溶 & 血 & 露 & 健 常 & & \multicolumn{2}{|c|}{ 挽 } & 逵 & & 溶 & 血. & & 霓 & & \multirow{2}{*}{$\begin{array}{l}\text { 免 䢞 } \\
\text { 血球 } \\
\text { 凝集債 }\end{array}$} \\
\hline & 翡 跣 & 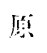 & 2 & 4 & 8 & 16 & 㒛集價 & 1000 & 2000 & $\because 000$ & 4000 & 5000 & 6000 & 7000 & $\$ 000$ & 9000 & 10000 & \\
\hline & 筑 33 距 & 强 & 弱 & 微 & 微 & - & 10 & 完 & 强 & 强 & 弱 & 弱 & 微 & 微 & 微 & - & - & 1000 \\
\hline & 第34號 & 微 & - & - & - & - & 10 & 完 & 完 & 强 & 强 & 弱 & 微 & 微 & 微 & - & - & 2000 \\
\hline & 第35號 & 先 & 完 & 始完 & 强 & - & 5 & 完 & 完 & 完 & 完 & 强 & 强 & 弱 & 弱 & 微 & - & 2000 \\
\hline & 第36號 & 弱 & 微 & - & - & - & 20 & 完 & 完 & 完 & 完 & 强 & 强 & 弱 & 微 & - & - & 2000 \\
\hline
\end{tabular}

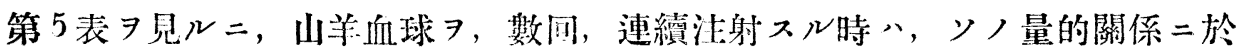
テモ，又y八同數，多察，或八注射後ノ時間的關係二於テモ，ソノ異種赤血球 令食作用ノ時間八，何レモ甚シク，短縮セルタ見ルベシ，而カモ第 6 表二示セ ルガ如ク，コレ管ノ溶血素淆生八何レモ高度也. 換言七バ，溶血素產生ノ旺盛 ナル時期ニ於テハ, 一方罢種赤血球，令食機能モ亦隆盛ナリ．

\section{第 4 章 沈降素産生卜異種赤血球嘪食作用々人關係}

凡齐動物性及植物性蛋白

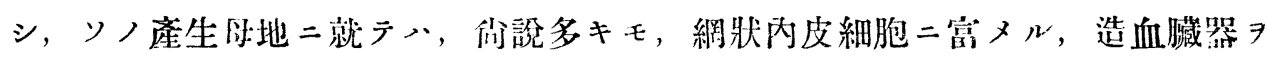
除外スル事能ハダルバシ。

余八健常篤血源 7 沈降原卜シ，家鬼ニ、ソノ一定量 71 同，或入數回洼射シ，

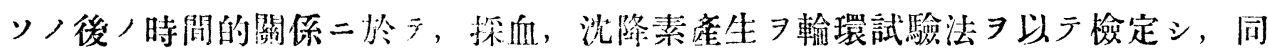

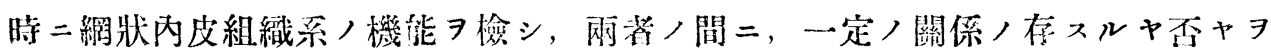
見タリ。

\section{第 1 節 健常臨血清1回注射卜異種赤血球 頞食卜ノ關係}

\begin{tabular}{|c|c|c|c|c|c|c|c|c|c|c|c|c|c|c|c|c|c|}
\hline \multirow{2}{*}{ 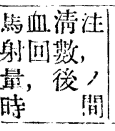 } & \multirow{2}{*}{$\begin{array}{l}\text { 家槐 } \\
\text { 番胧 }\end{array}$} & \multirow[b]{2}{*}{ 性: } & \multirow{2}{*}{$\left|\begin{array}{l}\text { 體重 } \\
(g)\end{array}\right|$} & \multirow{2}{*}{$\begin{array}{l}\text { 佔 球 } \\
\text { 清躬 } \\
\text { (cc) }\end{array}$} & \multicolumn{6}{|c|}{ 異種血球榊矢， } & \multicolumn{5}{|c|}{ 時間的關係 } & \multicolumn{2}{|c|}{ 沈 降 僋 } \\
\hline & & & & & 15 分 & 0 分 4 & 45 分 & 18 : & 牛: & 2 的 & 牛 & 3 時 & 4 時 & 5 時 & 695 & 前 & 後 \\
\hline 1 回 & 第37咜虎 & 崔 & 2000 & 100 & +1 & - & - & -1 & - & - & - & -1 & -1 & -1 & $1-$ & $\begin{array}{l}\text { 原液 } \\
(-)\end{array}$ & $\begin{array}{l}\text { 原液 } \\
(-)\end{array}$ \\
\hline 1 敊間後昘 & 第38號 & 此 & 2000 & & + & + & - & -1 & -1 & - & - & -1 & -1 & - & -1 & 原液 & $\begin{array}{l}\text { 原液 } \\
(-)\end{array}$ \\
\hline 1回 $80 \mathrm{cc}$ & 䇛39胧 & 此 & 1900 & & + & + & + & +1 & +1 & + & + & -1 & -1 & - & -1 & $\begin{array}{l}\text { 原液 } \\
(-)\end{array}$ & $\begin{array}{l}\text { 洷液 } \\
(-)\end{array}$ \\
\hline 1寺澗後| & & & & 95 & $1+1$ & + & + & +1 & + & +1 & + & +1 & -1 & -1 & -1 & $\begin{array}{l}\text { 原淮 } \\
(-)\end{array}$ & \\
\hline
\end{tabular}




\begin{tabular}{|c|c|c|c|c|c|c|c|c|c|c|c|c|c|c|c|c|c|}
\hline \multirow{2}{*}{ 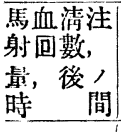 } & \multirow{2}{*}{$\begin{array}{l}\text { 家鬼 } \\
\text { 番號 }\end{array}$} & \multirow{2}{*}{ 性 } & \multirow{2}{*}{$\begin{array}{l}\text { 體重 } \\
(\mathrm{g})\end{array}$} & \multirow{2}{*}{$\left|\begin{array}{c}\text { 血 球 } \\
\text { 洼射 } \\
\text { (cc) }\end{array}\right|$} & \multicolumn{11}{|c|}{ 異種 血球消失，時間的關 保 } & \multicolumn{2}{|c|}{ 洮 绦 雷 } \\
\hline & & & & & 15 分 & :0分 & 4 汾 & 1時 & 本 & 2時 & 卅 & 3時 & 4 時 & 5時 & 6時 & 前 & 後 \\
\hline \multirow{2}{*}{$\begin{array}{c}1 \text { 回 } \\
2.0 \mathrm{cc} \\
24 \text { 時間後 }\end{array}$} & 第41號 & 雌 & 2000 & 100 & + & + & + & + & & + & - & 一 & - & - & - & & $($ 原液 \\
\hline & 第42號 & 雄 & 2000 & 10.0 & + & + & + & + & 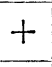 & + & - & - & - & -1 & - & 原液 & $\begin{array}{l}\text { 原液 } \\
(-)\end{array}$ \\
\hline \multirow{2}{*}{$\begin{array}{l}1 \text { 回 } \\
2.0 \mathrm{cc} \\
5 \text { 日後 }\end{array}$} & & 雄 & & & + & + & + & + & & - & - & - & - & - & - & & \\
\hline & & 雄 & & & & + & 1 & + & 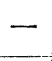 & - & - & - & - & -1 & - & $\begin{array}{l}\text { 原液 } \\
(-1)\end{array}$ & \\
\hline \multirow{2}{*}{$\begin{array}{l}1 \text { 回 } \\
2.0 \mathrm{cc} \\
7 \text { 日後 }\end{array}$} & & 雌 & & & + & + & + & + & - & - & - & 一 & - & - & - & & \\
\hline & & 雄 & & & t & + & + & - & - & - & - & - & - & - & - & $\begin{array}{l}\text { 原液 } \\
(-)\end{array}$ & $-)$ \\
\hline \multirow{2}{*}{$\begin{array}{l}1 \text { 回 } \\
2.0 \mathrm{cc} \\
10 \text { 日後 }\end{array}$} & & 雄 & 2100 & 10.5 & + & - & - & - & - & - & - & - & - & - & - & $\begin{array}{l}\text { 原液 } \\
(-1)\end{array}$ & +1 \\
\hline & 48號 & 雄 & 2000 & 10.0 & + & - & - & - & & - & - & - & - & - & - & $\begin{array}{l}\text { 原液 } \\
(-)\end{array}$ & $\begin{array}{l}1000 \text { 倍 } \\
(+)\end{array}$ \\
\hline
\end{tabular}

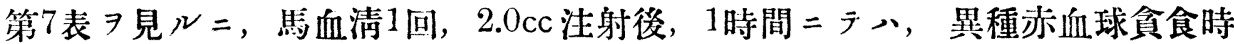
間，短縮サレ，15分万至 30 分以內二消失サル、モ，馬血清 $ᄏ$ 增量 1 回， $8.0 \mathrm{cc}=$ 及ブ時ハ，ソノ1時間後二於ヶル異種赤血球貪食時間，却而延言サレ，3時間二 亘ルモノアリ。㕛馬血清1回，2.0cc ヨ注射後24時間ニテハ，ソノ異程赫血球消 失時間、，正常家兔ノソレニ比シ，ヤ、延長サレ， 2 時問以队 $=$ 消失スルモ， 己 $=5$ 日後二至ル時ハ, 正常ノソレニ等シク, 7 日後ニハ, 正常ノソレョリ 、稍 タ短縮サレ，1回， $2.0 \mathrm{cc}$ 注射後 10 日二及ブ時ハ，ソノ異種赤血球食食時間八著 シク短縮サレ, 15 分以內 $=$ 消失スルヨ見ル.

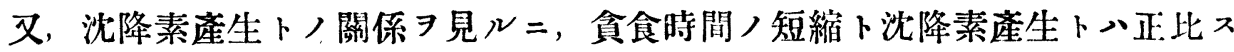
ルガ如シ, 唯 1 回, 小量注射ノ際ハ未ダ沈降素ノ出現 7 見ザルモ, ソノ食食時 間短縮省ル。

\section{第 2 篩 健常馬血清數回注射队異種赤血球}

\section{會食作用}

第 8 表

\begin{tabular}{|c|c|c|c|c|c|c|c|c|c|c|c|c|c|c|c|c|c|}
\hline \multirow{2}{*}{$\begin{array}{l}\text { 馬血清注 } \\
\text { 射回數, } \\
\text { 量, 後, } \\
\text { 時 间 }\end{array}$} & \multirow{2}{*}{$\begin{array}{l}\text { 家患 } \\
\text { 番號 }\end{array}$} & \multirow{2}{*}{ 性 } & \multirow{2}{*}{$\begin{array}{l}\text { 體重 } \\
(\mathrm{g})\end{array}$} & \multirow{2}{*}{$\begin{array}{l}\text { 血. 球 } \\
\text { 注射量 } \\
\text { (cc) }\end{array}$} & \multicolumn{11}{|c|}{ 珙種血球消失，時㳉的關係 } & \multicolumn{2}{|c|}{ 沈 降 瑻 } \\
\hline & & & & & 15 分 & 30 分 & 45 分 & 1 時 & 牛 & 2 時 & 4 & 3 時 & 4時 & 5 時 & 6 時 & 前 & \\
\hline $\begin{array}{c}2[\text { 回(間 } \\
\text { 隔4日) }\end{array}$ & 第49號 & 雄 & 2400 & 12.0 & + & + & + & + & - & - & - & - & - & - & & $($ 湶液 & $\begin{array}{c}2000 \text { 倍 } \\
(+)\end{array}$ \\
\hline $\begin{array}{r}2.0 \mathrm{cc} \\
10 \text { 日後 }\end{array}$ & 第 50 & 雄 & 2000 & 10.0 & + & + & + & + & + & - & - & & & - & - & $\begin{array}{l}\text { 原液 } \\
(-)\end{array}$ & $\begin{array}{c}1000 \text { 倍 } \\
(+)\end{array}$ \\
\hline
\end{tabular}




\begin{tabular}{|c|c|c|c|c|c|c|c|c|c|c|c|c|c|c|c|c|c|}
\hline \multirow{2}{*}{$\begin{array}{l}\text { 馬血清注 } \\
\text { 射回數, } \\
\text { 量, 後, } \\
\text { 腑 }\end{array}$} & \multirow{2}{*}{$\begin{array}{l}\text { 家鬼 } \\
\text { 番號 }\end{array}$} & \multirow[b]{2}{*}{ 性 } & \multirow{2}{*}{$\begin{array}{c}\text { 體重 } \\
(\mathrm{g})\end{array}$} & \multirow{2}{*}{$\begin{array}{l}\text { 血球 } \\
\text { 注射量 } \\
\text { (cc) }\end{array}$} & \multicolumn{11}{|c|}{ 異種血球消失，時間的關倸 } & \multicolumn{2}{|c|}{ 沈 降 價 } \\
\hline & & & & & 15 分 & 30 分 & 45 分 & 1 時 & 牛 & 2時 & 坐 & 3時 & 4 時 & 5 時 & 6 時 & 前 & 後 \\
\hline $\begin{array}{c}3 \text { 回(間 } \\
\text { 融4日) }\end{array}$ & 第51號 & 雄 & 2000 & 10.0 & + & + & + & + & + & + & - & - & - & - & - & $\begin{array}{l}\text { 原液 } \\
(-)\end{array}$ & $\mid \begin{array}{c}2000 \text { 倍 } \\
(+)\end{array}$ \\
\hline $\begin{array}{r}2.0 \mathrm{cc} \\
10 \text { 日後 }\end{array}$ & 第 52 號 & 蜼 & 2000 & 10.0 & + & + & + & + & + & - & - & - & - & - & 一 & $\begin{array}{l}\text { 原液 } \\
(-)\end{array}$ & $\begin{array}{l}800 \text { 倍 } \\
(+)\end{array}$ \\
\hline $\begin{array}{l}7 \text { 间 } \\
\text { (海吸) }\end{array}$ & 第53號 & 雌 & 2200 & 11.0 & + & + & + & - & - & - & - & - & - & - & - & $\begin{array}{l}\text { 原液 } \\
(-)\end{array}$ & {$\left[\begin{array}{c}1000 \text { 倍 } \\
(+)\end{array}\right.$} \\
\hline $\begin{array}{c}20 \mathrm{cc} \\
24 \text { 時間後 }\end{array}$ & & 雌 & 2000 & 10.0 & + & + & + & - & 一 & - & - & - & - & -1 & - & $\begin{array}{l}\text { 原液 } \\
(-)\end{array}$ & 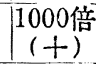 \\
\hline $\begin{array}{c}15 \text { [间 } \\
(\text { 每日) }\end{array}$ & & 雄 & 2200 & 11.0 & + & - & - & - & - & - & - & - & - & 一 & - & $\begin{array}{l}\text { 原液 } \\
(-)\end{array}$ & $\begin{array}{c}1000 \text { 倍 } \\
(+)\end{array}$ \\
\hline $\begin{array}{c}2.0 \mathrm{ccc} \\
24 \text { 特間後 }\end{array}$ & & 雄 & 2100 & 10.5 & + & - & - & - & - & - & - & - & 一 & - & - & $\begin{array}{l}\text { 原液 } \\
(-)\end{array}$ & $\begin{array}{c}2000 \text { 倍 } \\
(+)\end{array}$ \\
\hline
\end{tabular}

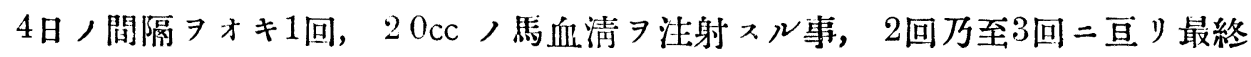
ノ注射ヨリ, 10 日後二於テ, 異柍赤血球会食機能 7 見 $ル ニ$, 兩者共二, 正常, ソレト殆ンド等シキモ，每日連續的二注射 $(1$ 回, $2.0 \mathrm{cc}$ 宛) スル事7回, 乃至 15 回 ニ及ブモノニアリテハ，ソノ食食時間短縮サレ，コトニ1う回連續ノモノハ，尤 モ甚シク15分以內二消失スルフ見ル。

又沈降素產生卜良食ノ時間卜 7 比較スル

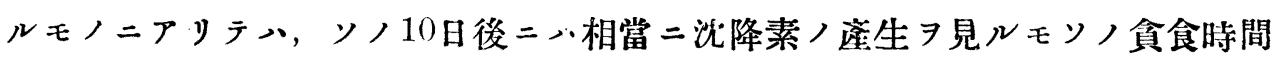
メ殆ンド正常ノソレニ等シ, コレ或・一度變化サレシ機能ガ正常ノ狀態二快復 セラレシニハアラザルカ, 更二連續洼射 7 回乃至 1 回二至ルモノ八, ソノ沈降 素ノ產生モ可ナり高度ニシテ, ソノ食食機能二比例ス。

\section{第 5 章 總括及考察}

凝集素, 溶血素及沈降素迹生卜異種赤血球会食作用卜ノ關係 $习$ 明ニセントシ テ，如上ノ實驗

即于, 凝集素產生卜, ソ/貪食時間卜 $\exists$ 比較スルニ, 1 回注射/際入（菌液 2.0--0.2cc） 1 時間及 24 時間後二於テメ，何レモ正常動物ノソレニ比シ延長サル 、モ, 1回注射後7日二至ラバ, 漸次短縮サレ, 正常動物ノソレト等シクナル, 更二連續注射ニテハ, ソノ回数及量的關係习考虑スルモ, 正常動物ノ, ソレニ 比シ短縮サル。即于如上ノ量的關係二於テハ凝集素產生ト食食機能トハ正シク 相比例 $ᄌ$.

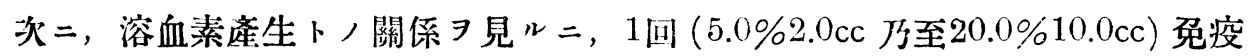


後，1時間乃至5日迄ノ異種赤血球荛食時間八，正常動物八，ソレ二比シ，何レ

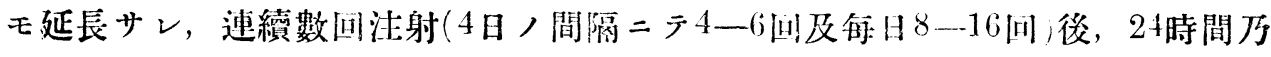
至 5 日ニテハ，ソノ会食時間短維サル．即チ如上ノ量的關係二於テハ，溶血素 產生作用卜貪食機能卜 、相正比ス.

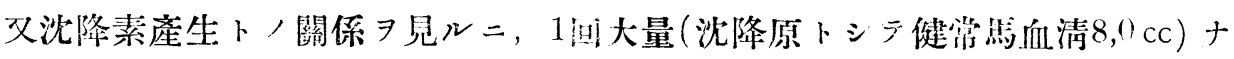

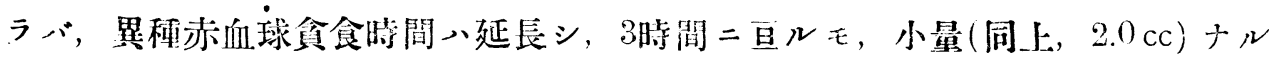

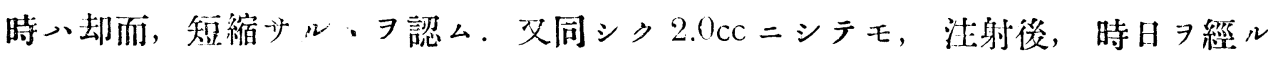

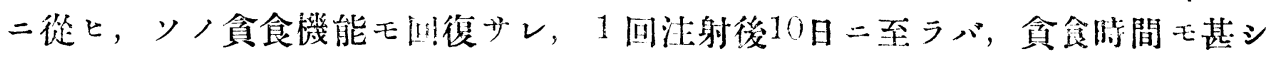

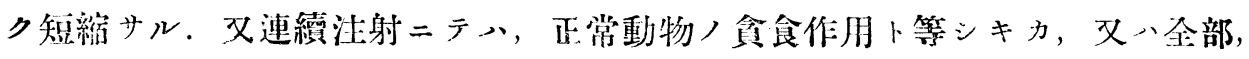

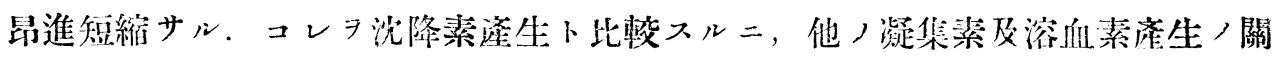

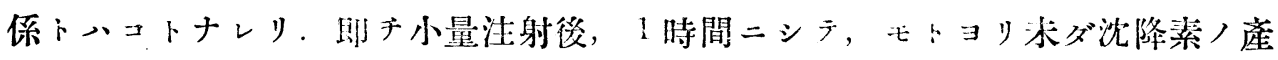
生ナキ，時期二モ，力、メラバ，ソノ食食作用促進サレス，大量ナル時八，同 ジク 1 時間後ニテモ, ソノ機能障碍省ル, 次 $=1$ 回注射ソ, 後ノ時間二於テ度連

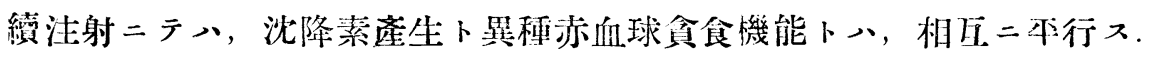

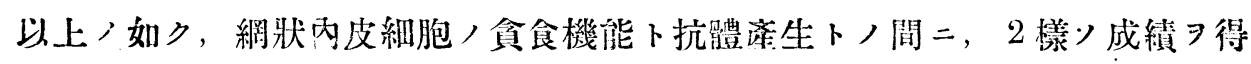
タリ。即于凝集素及溶血素產生卜, ソ, 食食機能”, 正二比例スルモ, 沈降素 ニアリテハ, 未ダソノ產生ナキ際ニモ係ハラバ, 極メテ小量ノ抗元 時ハ, ソノ貪食機能昂淮スル事コレナリ。 カ、ル點ヨリ推定スルニ, 恐ラク凝

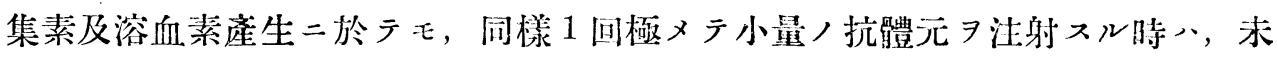

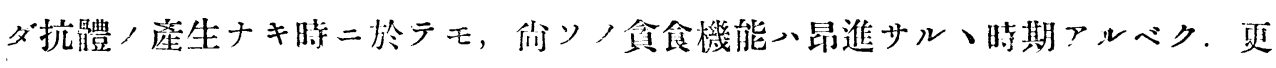

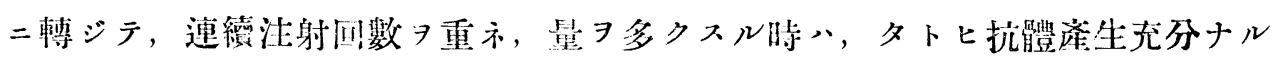

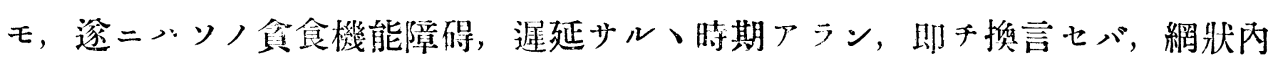

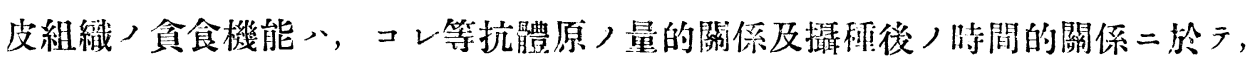
或、刺战サレ或、障得サル、モノナラン.

\section{結論}

以上ノ實驗 ヨ綜合セバ，

1, 免疫抗體產生卜，異種赤血球食食作用ト，，間二八一定，關係アルタ認 么. 


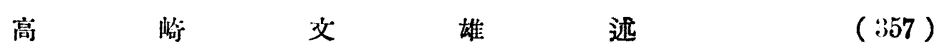

2, 膓䇪扶斯菌液, 1 回，及連續注射ニョリテ，如上ノ量的關係二於テハ,

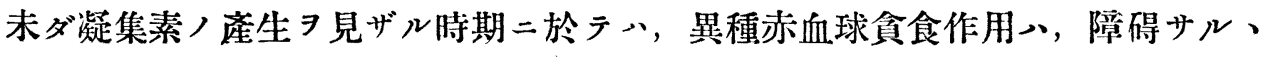
モ，ソノ産生ヨ見ルニ至り，又高度二產生サル、ニビ，ソノ貪食作用モ亦， 快復, 促進サル、ヨ認ム。

3 , 溶血素產生卜，異種赤血球昘食作用モ亦，如上ノ量的關係二於テハ，溶 血素, 產生ヨ見ザルカ, 或一輕度ナル時ハ, ソノ食食機能モ障碍サル, 然レ临 己二溶血素產生高度二及ブニ至リ，ソノ貪食機能モ亦昂淮サル。

4, 黑種赫血球食食作用卜, 沈降素產生卜 /關係八, 前 2 者二比シ, 稍暴 リ. 即チ小量 1 回注射ノ際ハ, 未ダ沈降素ノ産生ナキ将期ニ於テモ, ソノ食食 機能ハ昂進サル、事コレナリ。然レ共大量注射ノ㷪合及小量二テモ，24时間以 後ノ時間的關係二於テ, 又連續注射二於テモ, 沈降素產生 $r$, 異種赫血球舍食 作用トハ互二正比ス.

5 , 以上ノ處見 $=ヨ リ$, 網狀內皮細胞 $=$ 富メル, 造血臟器八, 否朘性抗原二 ヨリ，或ハ刺戟サレ，或ハ障碍サル，而シテソノ機能ヨ，流血中ノ異種赤血 球, 消失ノ時間的關係ニョリテ, 推知スル事 $\exists$ 得.

\section{まナル引用文献}

（大正15年7月脫稿）

1) Memmescheimer u. Klövekorn, Über die Funktionsprüfung der Abfangsorgane des Retikuloendothelialen Systems bei der Lules. Klinische Wochenschr. 4. Jahrgang, Nr. 46, S. 2204. 2) Coca, Die Ursache des plötzliches Todes bei intıavenöser Jnjektion artfrem des Blutkörperchen., Virchow's Arch. Bd. 196. S. 92. Iso9. 3) Gowan, The fate of hen corpuscles when injected intravlnonsly into rabbits, with some considerations as to the seat of the formation of immune body. Jour. of Path. \& Bact. Vol. 14. P. 379. 1910.

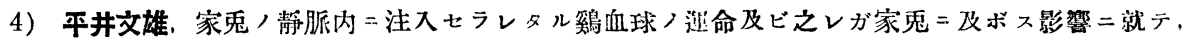
京都醫學雜誌，第18怣，大正10年.

5) 鈴木次男, あんちげん/氣拳内接璉二就テ，鮞生學 傳染病學雜誌，第18策，大正11，12年.

6）柏原笑兒, 生體内二於ヶ儿買種赤血球，運命卜

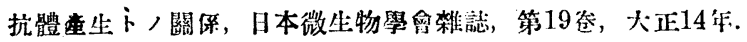

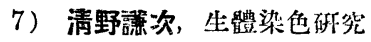
，現㫛及其檢查術式，大正10年. 8）清野潇次, Vitale Karminspeieherung.

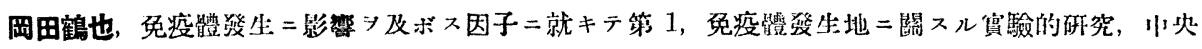

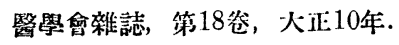

10）佐久間利久，銀ぞーる/㷋集素座生二及ボ影響, 衛生學傅染病學雜誌, 第19卷, 大五 12,13 年, 420頁. 11） Ffeiffer u. Marx, Die Bildungsstätte der Choleraschutzstoffe Zeitschrift f. Hygiene, Bd. 27. S. 272. 1898. 12) van Emden, Ueber die Bildungsstätte der agglutinierende Substanzen bei der Jnfektion mit 
Bacillus Aërogenes, Zeits. f. Hygiene, Bd. 30. S. 19. 1899. 13) Jatta, Experimentelle Untersuchungen über die Aggluitnation des Typhusabcillus und der Mikroorgnaismen der Coligruppe. Zeits. f. Hygiene, Bd. 33. S. 185. 1900. 14) Deutsch, Origine des ant corps typhiques, Annales de L'institut Pasteur, Tome 13. S. 689. I899. 15) Rath, Ueber den Einfluss des blutbildenden Organe auf die Entstehung der Agglutinine. Centralbratt $f$. Bakteriolgie, Bd. 25. S. 549. I899. 16) Castellanie, Ueber das Verhältniss der Agglutinine zu den Schutzkörpern. Zeits. f. Hygiene, Bd. 37. S. 38r. 19or. 17) Brezina, Zur Frage der Bildungsstätte der Autikörper. Wiener klin. Wochens. Bd. 17. No. 35. S. g05.

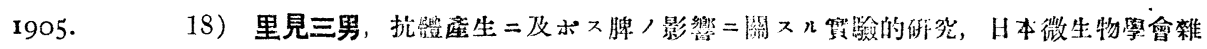
誌, 第17卷, 1945頁, 大正12年, 及第18炝, 80頁, 火五13年, 19) jakuschewitsch, Ueber Haemolysine bei entmilzten Tieren. Zeitschr. f. Hygiene, Bd. 47. S. 407. 1904. 20)

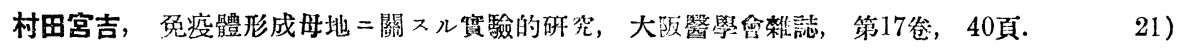

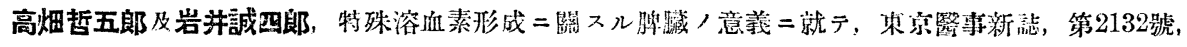
1225賈，大正8年.

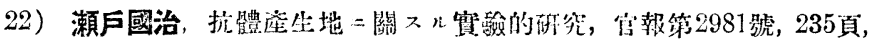
大正11年7月. 23) Wassermann u. Citron, Die lokale Immunität der Gewebe und ihre praktische Wichtigkeit. Deutsch. med. Wochens. Nr. I5. S. 573. 1905. 